\title{
Use of Modal Verbs as Stance Markers in Pakistani English Newspaper Editorials
}

\author{
Muhammad Ahmad \\ SSE English, Government High School, Hujra Shah Muqeem, Okara, PAKISTAN \\ (iD) 0000-0001-6759-9511 \\ ๑ahmad453@yandex.com
}

\section{Dr. Muhammad Asim Mahmood}

Chairman Department of Applied Linguistics, Government College University, Faisalabad, PAKISTAN

(iD) 0000-0002-8377-2289

\section{Dr. Muhammad Ilyas Mahmood}

Head of English Department, University of Okara, Okara, PAKISTAN

(D) 0000-0001-5329-758X

\section{Ali Raza Siddique}

Lecturer in English, Department of Applied Linguistics, Government College University, Faisalabad, PAKISTAN

(D) 0000-0003-1946-2347

\section{ARTICLE INFO}

Received: 15 December 2018

Accepted: 12 February 2019

Published: 26 February 2019

DOI: https://doi.org/10.29333/ojcmt/5722

ABSTRACT

This study investigates the use of modal verbs as stance markers in Pakistani English newspaper editorials. For this purpose, corpora of 1000 editorials have been developed from the editorials published in The News, The Dawn, The Frontier and The Express Tribune (250 editorials from each newspaper) and analyzed using AntConc 3.4.4.0. Results reveal that prediction, possibility and necessity are the characteristic features of Pakistani English newspaper editorials and the writers of these editorials use modality to report, comment or inform about the state of affairs. Results also show that the main focus of Pakistani English newspapers' editorials is on depicting 'what will happen', 'what may happen' and 'what is needed to happen'. On the basis of these results, the study concludes that modality, being an important linguistic property, is used by the editorialists to maintain interaction with readers, establish authorial persona and present personal as well as institutional stance. To cipher readers' negative perception about stance, the editorialists make a skillful use of intermediate-value modals. Study suggests the editorial readers to be aware of the writer's stance marking. For, it may influence mind and manipulate opinions.

Keywords: editorialists' stance, editorials' characteristic features, modality in editorials, modal verbs as stance markers, stance in newspaper editorials

\section{INTRODUCTION}

The presence of modality and stance has been observed in many studies (e.g. Adams \& Quintana-Toledo, 2013; Biber, 2004; Bista, 2009; Butler, 1990; Chang, 2010, 2012; Chang 
M. Ahmad, et al.

\& Schleppegrell, 2011, 2016; He \& Wang, 2012; Holmes, 1988; Hunston \& Thompson, 2000; Hyland, 1996; Kuppers, 2012; Maks \& Vossen, 2010; Mirahayuni, 2002; Nartey \& Yankson, 2014; Ngula, 2017; Panocova, 2008; Pho, 2013; Shayegh, 2012; Shayegh \& Nabifar, 2012; Taavitsainen, 2001; Wang \& Jiang, 2018). Study by Taavitsainen (2001) traces the use of modality or mood in medical register. Biber's (2004) research finds stance in a multi-register corpus, a view from history, and concludes that stance marking differs across registers i.e. strategies of stance, even with same functions, may be different from register to register. Similarly, their frequency can also decrease or increase. Butler (1990) and Hyland (1996) highlighted modality in scientific writing. In the same way, Holmes (1988) found modality in ESP and EAP textbooks. Chang (2010, 2012), Chang and Schleppegrell (2011, 2016), He and Wang (2012), Mirahayuni (2002) and Panocova (2008) observed modality in non-native speakers' academic writing. Hunston and Thompson (2000) discovered stance in discourse. Bista (2009), Maks and Vossen (2010), Shayegh (2012) and Shayegh and Nabifar (2012) explored the stance in political discourse and in much the same way, Kupper (2012) recorded the presence of stance in business communication letters. Nartey and Yankson (2014) explored the use of modals and modality in political manifestos. Adams and Quintana-Toledo (2013), Ngula (2017) and Pho (2013) explored modality in research articles. Similarly, Wang and Jiang (2018) reported the use of stance in scientific research writings.

All of above studies sufficiently prove that stance is present in almost every type of writing. However, this study presents an investigation of modality and stance marking in newspapers with a special focus on the editorial texts selected for this study from four famous Pakistani English newspapers. It involves the major principles in the study of stance marking through modal verbs as well as the other terminologies linked with it (see at Page 4). For, a number of studies (e.g. Bonyadi, 2011; Fowler, 2013; Gajevic, 2016; Golan \& Lukito, 2017; Halliday, 1994; Hayat \& Juliana, 2016; Hindman, 2003; Kelling \& Thomas, 2018; Khalid, 2013; Lawal, 2015; Ntsane, 2015; Porten-Chee, 2017; Rosenfeld, 2000; Sadia \& Ghani, 2018) have also highlighted stance marked through modals in world renowned English newspaper editorials and there is a possibility that Pakistani English newspapers might also be presenting stance through the editorials. Thus, the study aims to:

1. Examine the use of modality by Pakistani English newspaper editorial writers, and

2. Make readers of Pakistani English newspaper editorials aware of the fact that these editorialists may make use of modal verbs to influence mind and manipulate opinion.

To stick particularly to its aims, the study concerns following questions:

1. Which modals are most frequently used by Pakistani English newspaper editorials writers?

2. Do Pakistani English newspaper editorial writers use modals to influence readers' mind and manipulate opinion?

\section{LITERATURE REVIEW}

Any study about modal verbs requires, at first, a definition and a list of modal verbs, their semantic meanings, linguistic characteristics, relative frequencies and general functions in various settings. However, to cover a complete discussion of just the semantics of modal verbs is impossible in this study. Therefore, it gives just a review of 
the forms, meanings and functions of different modal verbs, and after that discusses the frequencies of these forms in newspaper editorials.

Modal verbs are commonly considered as the verbs like will, shall, would, should, can, could, may and might (Biber, Johansson, Leech, Conrad, \& Finegan, 1999). These verb forms are differentiated from lexical verbs on the basis of following features presented by Hailiday (1976): (1) they do not have any finite forms, like -ing, -ed, etc. for example 'maying, to may'; (2) interrogative and negative forms of the modals are made without any extension. It is not needed for the modal verbs to incorporate 'to be' or 'to do' frames while making questions or putting forth negative expressions with modal verbs like 'they may not' or 'would they be able to run?' instead of 'would she say she is can go? and 'he doesn't will' and so forth; (3) negative forms of the modal auxiliaries are reducible. They can be contracted, as in 'She can't drive a car' or 'We won't have the capacity to drive a bike'; (4) they can be utilized as 'code verbs' in ellipsis. This implies when two comparable clauses, utilizing a modal happen to come together the second clause does not require to repeat the following lexical verb, as in 'She can run so can I'. For this situation, the second modal verb 'can' represents the lexical verb 'go'; (5) they do not require a third person singular 's', for example, 'He cans' and (5) they do not combine with one another and do not co-occur in a clause (except in some nonstandard clauses like 'They may could run'.

Regardless of these features, Biber et al. (1999) opine that the difference between lexical and modal verbs is vague. Normally, some of the non modular i.e. lexical verbs can also work as modal verbs, particularly in spoken contexts. These forms are arranged in two separate categories. One category belongs to auxiliaries and it incorporates 'need to', 'used to' and 'dare to' etc. These verbs have features which are quite similar to those of modal verbs, e.g. negative and interrogative forms like 'dare not', 'needn't', 'need they?' Biber et al. (1999) incorporate 'ought' in this group. The other category is called quasi or semi-modals. Modal verbs of this category include; 'be going to', 'be supposed to', 'have got to', 'have to' 'had better', etc. These colloquial expressions work as the forms of modality yet can also be used for tense markers (Biber et al., 1999).

Modality is specifically related with attitude of the speakers towards the truth of a situation expressed in the utterance. (Huddleston \& Pullum, 2005: 173) presented two examples which represented the term "modality': "He wrote it himself" and "He must have written it himself". When we see the first sentence, it seems as un-modalised due to the fact that the speaker has used it in normal situation without any emphasis on the truth of the proposition expressed. Whereas, the second statement seems as being modalised. Truth of the proposition has not been presented as something directly referred to. Instead, it has been referred to as something based on inferencing (Huddleston \& Pullum, 2005). In the opinion of Quirk, Greenbaum, Leech and Svartvik (1985), modality may be defined as the way, the meaning of a statement is conveyed in order to express the judgement of a speaker.

When a person compares above definitions he finds them giving similar meaning by using different words. These definitions suggest that modality means a manner by which a text can express attitudes towards a particular situation. This feature of modality makes it something quite different from a direct proposition. Hyland $(1994,1998)$ relates the concept of hedging with that of epistemic modality since both of them express certain degrees of belief or confidence of the speakers or writers about the certainty of a statement. Lexical category, as mentioned earlier, is commonly connected with epistemic modality. To avoid any misunderstanding of these categories, Coates (1983) and Palmer (2007) presented a reasonably clear difference between deontic and epistemic modalities 
i.e. the later expressed the opinion of a speaker about the reality of what was being said, while the former demonstrated the speakers' perceptions about the obligation or necessity to perform specific activities. For instance: (a) 'You may have completed that. (epistemic modality expressing possibility) and (b) 'She may do it'. (deontic modality expressing permission). However, sometimes it is difficult to differentiate between these two kinds of modality and acknowledge whether the writer has used to hedge his statement or not. Palmer (2007) gives a few examples of these modalities stating that it is through the contexts that the listeners or readers can derive the speaker's or writer's intentions. For example: (i) 'They may leave tomorrow' (possibility/belief/permission) and (ii) 'The towel ought to be on the hook' (weak order/request/assumption). Putting the said similarities as well as dissimilarities aside, the focus of this study, based on the available literature, is just on the use of following verbs: will, shall, would, should, can, could, may, might; some modal adverbs: like unlikely, apparently, clearly, truly, accurately, unacceptably, surely; some evaluative adverbs: like seriously, painfully, deadly, badly, sadly, chiefly, unfortunately, ruthlessly, efficiently, rapidly; some reporting verbs: like claim, warn, declare, hope, doubt, predict; some knowledge verbs: like seem, appear, believe; and certain generaic phrases: like it seems that, there is no doubt that, it is obvious that.

A newspaper assumes that there is always only one reasonable point of view on any matter presented to the public. The editorial seems to affirm this point of view. For, an editorial represents the opinion of the newspaper owners (Kelling \& Thomas, 2018; Hindman, 2003) called it as being an institutional voice. Similarly, Gajevic (2016) called it organizational stance. And most of the times editorials are affected by the notions of homophily (Katz \& Lazarzfeld, 1955) and are also value-oriented (Porten-Chee, 2017). In the view of Rosenfeld (2000), editorials provide subjective evaluation of highly debated and contested issues whereas, according to Golan and Lukito (2017), editorials give voice to the newspaper's institutional worldview. Editorials, says Indarti (2018), are written to influence readers' opinions on controversial issues. (Fowler, 2013) points out that what is true about newspaper editorials, apart from offering values and beliefs, is that they employ textual strategies which foreground the speech act of offering values and beliefs. It is, of course, these textual strategies which are adopted by the editorial writers who are the concern of this study.

Modal expressions signify judgement as truth (correct), likelihood (certainty) and possibility (might). Other modal usages stipulate obligations (should, ought to) and grant permission ('may'). This linguistic device (modality) is an important means for editorial writers to have the insistence of a speaker who has assumed a position of authority, the authority here includes a claim to know what is inevitably going to happen. Herndon (1976) shares this view when she points out that a sentence is made up of a modality constituent that includes tense and sentence modifiers such as negation. According to her, this proposition is a verb or additional noun phrase-each of which is related with the verb in a situational relationship. This alteration is actually central to the work because it really shows the extent to which the writer is committed to any statement written in newspaper editorials.

Papafragou (2005) sees truth-conditionality from the epistemic view of modality. She counters the epistemic position of modality that it does not contribute to truth-conditional content, using Halliday's (1976) argument that modality is external to the content of any proposition and thus, constitutes the attitude taken up by the speaker. This means that modality represents the opinion of any speaker or writer and not any total commitment to the truth of a statement. Gotti (2003), focusing on the Helsinki corpus of English texts, 
found the commonly used 'verbatim expression', in contrast to the simplest common figures for the 'shall' form in scientific articles. Smith (2003) focuses on diachronic development, and it must be pointed out that the use of 'must' is most concentrated in fiction and genre, with the most important development of news reports. These two studies have shown that samples can reflect the general characteristics of a particular type.

Bonyadi (2011), in his study based on comparative textual analysis of editorials published in American and Persian English newspapers, noticed that the writers used auxiliaries of prediction i.e. 'will' and 'would' in their editorials. The study also reported a difference that prediction modals were used most frequently by American newspaper editorial writers as compared to Iranian writers who used the modals of necessity with greater frequency. The study called modality as a linguistic property which the language users could use to create favourable or unfavourable bias or to manipulate the opinion of readers.

Khalid (2013) conducted a research to examine the presence of authorial subjectivity in Scottish English newspaper articles. Results revealed that the modals work as the indicators of ability, permission, possibility and the Scottish newspaper article writers depended on modals to infuse their voice into the text, to maintain authorial presence in the text and to establish contact with their readers.

Ntsane (2015) investigated the process of interaction management between an editorialist and his readers to know that how the editorialists engage a reader as a participant in the argument while establishing their authoritative persona. Plus, he investigated that how the editorialists made their readers align with their views. Results reveal that the editorialists utilize modality to establish their authority and interaction or engagement with readers.

According to Lawal (2015) press makes use of modality as a method to report news. The reason for it, as he states, is that modality involves the claim of a person assuming the position of authority and claiming or asserting to have knowledge of what will happen in future. He regards 'must' crucial for editorial text writers to exercise the right to claim of knowing about future happenings. He adds that editors have to follow the ideology of the newspaper. Therefore, they make use of modals subjectively. Hence, the editorial writers may not be committed to the truth of propositions.

In the view of Sadia and Ghani (2018) modality is a significant aspect of grammar which finds its expression in a newspaper's editorial section. Moreover, Pakistani English newspaper editorial writers use modal verbs to influence readers' minds to manipulate their opinion towards specific issues. In addition, Pakistani English newspaper editorialists make use of predictive modal verbs i.e. 'will' and 'would' most frequently.

Above literature leads to form a general view that editorials are an important part of the newspapers which present editors', newspapers', institutions' or organizations' stance and thus, are subjective. Moreover, modality is a linguistic property which is used by editorial writers to infuse their voice in editorial texts, maintain contact with readers and establish authorial persona.

\section{METHODOLOGY}

Corpora of the Study

This study employs purposeful sampling to select and develop the corpora. Let it be made cleared that this study is not corpus based. Rather, it is corpus driven. Major reason 
M. Ahmad, et al.

\begin{tabular}{lccc}
\hline Table 1. Corpora Length & & \\
\hline Name of Newspaper & No. of Editorials & Word Types & Word Tokens \\
\hline The News & 250 & 9,633 & 103,860 \\
The Dawn & 250 & 10,053 & 103,596 \\
The Frontier & 250 & 14812 & 172878 \\
The Express Tribune & 250 & 9737 & 93048 \\
Total & $\mathbf{1 0 0 0}$ & $\mathbf{4 4 , 2 3 5}$ & $\mathbf{4 7 3 , 3 8 2}$ \\
\hline
\end{tabular}

behind it includes: (1) study focuses on the use of modality for stance marking in Pakistani newspaper editorials. Hence, to assist to a new research, 1000 English newspaper editorials' corpora have been driven from a bigger sample of a previous study, (250 editorials from 'The Dawn', 250 editorials from 'The News', 250 editorials from 'The Frontier' and 250 editorials from 'The Express Tribune'), published during the months of March-April, 2017. All of these four newspapers are ranked among top broadsheets on newspapers' official websites. 1000 editorials from the said newspapers have been considered sufficient enough to establish the degree of reliability being favourable or unfavourable. The reason behind it is that these editorials form a sound collection of data which can be analyzed meaningfully and purposefully on the ground that it represents the same variety of discourse i.e. editorials of attack, criticism, praise, defense etc.

\section{Corpora Retrieval}

As mentioned earlier, the corpora for this study ware retrieved from a previous study by Siddique (2017) to support to a new research. Retrieval process went through the following stages: (1) receiving data in electronic form with prior consent and permission of the researcher, (2) recording of the corpora in Microsoft Excel marking file number, token types, word types, sources, publication dates, etc., (3) renaming of editorials, (4) removing editorial titles, publication dates and author names, (5) conversion of the corpus files into notepad for processing in Antconc 3.4.4.0 processor and (6) collecting/gathering the editorials in one folder namely 'compiled up files 1 to 1000' which was further set/named as 'All Editorials (1-1000)'

\section{Distribution and length of corpora}

As it has already been mentioned, the corpora of this study comprise of 1000 editorials published in Pakistani highly esteemed English newspapers i.e. The News, The Dawn, The Frontier and The Express Tribune (250 editorials from each newspaper). Length of the corpora is given in the Table 1.

\section{Model}

Corpora of the study have been analyzed with the help of AntConc 3.4.4.0 and interpreted in the light of functional approach by Halliday (2004) which helps analyze the relationship between the types of modality i.e. (1) deontic and (2) epistemic, and the degrees of modality i.e. low, medium and high as being the ideology/stance markers.

\section{Tuning Procedure}

A tuning procedure for the modal expressions was devised to find the frequencies of modal expressions in the corpora using AntConc 3.4.4.0, 2014. The said expressions have been given in the Table 2 . 
Online Journal of Communication and Media Technologies, 2019

\begin{tabular}{|c|c|}
\hline Function/Expression & Modality/Modal Verb \\
\hline Prediction & will | would \\
\hline Possibility & can $\mid$ could $\mid$ may $\mid$ might \\
\hline Necessity & must | should \\
\hline Model Adverbs & $\begin{array}{l}\text { unlikely | undeniably | apparently | clearly | truly | accurately | unacceptedly | grandl } \\
\text { y | surely | genuinely | less likely }\end{array}$ \\
\hline Evaluative Adverbs & $\begin{array}{l}\text { woefully | substantionally | seriously | painfully | deadly | badly | sadly | cynically | che } \\
\text { ifly | not surprisingly | unfortunately | frighteningly | ruthlessly | efficiently } \\
\text { | uncritically | rapidly | understandably }\end{array}$ \\
\hline Reporting Verbs & $\begin{array}{l}\text { claim | voice | warn | declare | admit | speculate | hope | doubt | concede | predict | anno } \\
\text { unce | charge }\end{array}$ \\
\hline Knowledge Verbs & seem | appear | believe \\
\hline Generic Phrases & $\begin{array}{l}\text { It seems that | there is no doubt that |it is never acceptable |it makes us } \\
\text { wonder | doubts have now arisen |it is clear that|it is obvious that }\end{array}$ \\
\hline
\end{tabular}

\section{RESULTS}

Results of the study are as follows:

\section{Modal Expressions in 'The News'}

Results showed that the editorial writers used modal verbs in editorials published in The News. Frequency of the different modal verbs is as follows: (a) modal adverbs: (clearly, unlikely, truly, less likely, genuinely, apparently, accurately, unacceptably, surely) is 1; (b) of generic phrases (It is obvious that, It is never acceptable, There is no doubt that, It makes us wonder that, It seems that, Doubts have now arisen that, It is clear that) is 5; (c) of evaluative adverbs: (badly, chiefly, deadly, woefully, painfully, seriously, sadly, unfortunately, and understandably) is 22; (d) of knowledge verbs: (appear, believe, seem) is 25; (e) of reporting verbs: (warn, claim, admit, voice, hope, doubt, declare, announce) is 64; (f) of necessity: (like should, must) is 182; (g) of possibility: (can, could, may and might) is 363 and (h) of prediction: (will, would) is 695. In this way, the use of modal adverbs seems to be minimum whereas, the use of prediction expressions seems to be maximum in the editorials written by Pakistani editorialists for The News.

\section{Modal Expressions in 'The Dawn'}

Results revealed that the editorial writers used modality in editorials which were published in The Dawn. Frequency of (1) modal adverbs is 133, (2) of generic phrases is 4, (3) of evaluative adverbs is 54 , (4) of knowledge verbs is 75 , (5) of reporting verbs is 83 , (6) of necessity is 389 , (7) of possibility is 501 and finally (8) of prediction is 528. In this way, the use of generic phrases seems to be minimum and the use of prediction expressions seems to be maximum in the editorials written by Pakistani editorialists for The Dawn.

\section{Modal Expressions in 'The Frontier'}

The results showed that the editorial writers used modal verbs in editorials published in The Frontier. Frequencies of different modal verbs in the editorials published in the said newspaper are as follows: modal adverbs occurred 65 times, generic phrases happened to come 14 times, evaluative adverbs were seen 70 times, knowledge verbs were observed 66 times, reporting verbs were observed 144 times, necessity modals frequented 379 times, auxiliaries of possibility were noted 763 times and finally prediction modals were recorded 950 times. In this way, the use of modal adverbs seems to be minimum whereas the use of prediction expressions seems to be maximum in the editorials written by Pakistani editorialists for The Frontier. 
M. Ahmad, et al.

Table 3. Frequencies of Modal Verbs in Newspapers

\begin{tabular}{lcccc}
\hline Modality & The News & The Dawn & The Frontier & The Express Tribune \\
\hline Modal Adverbs & 1 & 133 & 65 & 59 \\
Generic Phrases & 5 & 4 & 14 & 17 \\
Evaluative Verbs & 22 & 54 & 70 & 32 \\
Knowledge Verbs & 25 & 75 & 66 & 64 \\
Reporting Verbs & 64 & 83 & 144 & 71 \\
Necessity & 182 & 389 & 379 & 146 \\
Possibility & 363 & 501 & 763 & 389 \\
Prediction & 695 & 528 & 950 & 457 \\
TOTAL & $\mathbf{1 3 5 7}$ & $\mathbf{1 7 6 7}$ & $\mathbf{2 4 5 1}$ & $\mathbf{1 2 3 5}$
\end{tabular}

\section{Modal Expressions in 'The Express Tribune'}

Like other newspapers, modal verbs were also observed in the editorials of The Express Tribune. The frequencies of modal adverbs, generic phrases, evaluative verbs, knowledge verbs, reporting verbs, necessity modals, possibility modals and prediction modals are 59, $17,32,64,71,146,389$ and 457 respectively. In this way, the use of generic phrases seems to be minimum and the use of prediction expressions seems to be maximum in the editorials written by Pakistani editorialists for The Express Tribune. Complete results have been given in the Table 3.

\section{Comparison of the Use of Modal Expressions in All the Four Newspapers}

It is evident from the above table that there are certain differences and certain similarities in the use of modal verbs in the editorials of The News and The Dawn, The Frontier and The Express Tribune newspapers. A difference is that the frequency of the modal adverb in The News is 1 but the frequency of the same in The Dawn, The Frontier and The Express Tribune is 133, 65 and 59 respectively. It means that The News makes less use of modal adverbs. However, the most frequently used modality in all the four newspapers' editorials is the same i.e. prediction modal verbs have been found in maximum use. Similarly, the modal verbs of possibility and necessity have been found to occur in $2^{\text {nd }}$ and $3^{\text {rd }}$ maximum frequency in all the four newspapers' editorials.

\section{DISCUSSION}

The first question of this study was to know about 'Which modal verbs are most frequently used by Pakistani English newspaper editorials writers?' To answer this question the use of different modals including generic expressions, modal verbs, reporting verbs, evaluative adjectives, modal adverbs, etc. were examined. The examination resulted in that Pakistani English newspaper editorialists made extensive use of the modal verbs of prediction i.e. 'will' and 'would'. This means that Pakistani English newspaper editorialists, while discussing the situations, make their own predictions about future happenings. It also highlights that prediction is the most important feature of Pakistani English newspaper editorials. Thus, this study validates the results of a recent study by Sadia and Ghani (2018). The same results have also been reported in a study by an Iranian researcher Bonyadi (2011). In addition, auxiliaries of possibility and necessity have been observed to occur in $2^{\text {nd }}$ and $3^{\text {rd }}$ maximum frequency. It means that Pakistani English newspapers editorials are mainly concerned with presenting 'what will happen' (prediction), 'what can happen' (possibility) and 'what is needed to happen' (necessity).

Halliday and Hasan (1989) classified modal verbs according to values into: (1) high (must, need to, have to, ought to); (2) intermediate (shall, should, will, would) and (3) low value modals (can, may, could, might). As the results of this study show that the editorial 
writers have used 'will' and 'would' with maximum frequency, it means that Pakistani English editorialists make frequent use of 'intermediate value' modal verbs. According to Qian (n. d.) different types of modal verbs are related with different degrees of politeness in communication process. In their function, low value modals show politeness in communication, whereas high value modals express impoliteness in communication. It implies that if the writers make use of high (impolite) and low degree (polite) modals, there can be the possibility for their writings to be approached negatively with writer's tilt in favour or against the situation. Therefore, it might be that the editorial writers make use of neither high nor low value modal verbs. Instead, they make conscious use of the intermediate value modals to cipher any negative perception among readers.

Modal verbs, in the view of Palmer (2007), help language users express 'what should be', 'what may be', 'what would be', and 'what is'. Thus, the writers make frequent use of modal verbs to show possibility, necessity and prediction in their writing. However, this is just one side of the coin. In fact, modality involves the claim/assertion of a person assuming the position of authority and claiming/asserting to have knowledge of what will happen in future (Lawal, 2015). Therefore, the editorial writers make use of modal verbs to predict about future on one hand, and to show their authority by claiming their knowledge of future happenings on the other. In addition, it is one of the main goals of the writer to maintain a relationship with readers to convey his ideas. For this purpose, the writers of newspaper editorials make a skillful use of modal verbs to infuse their voice into the text, to maintain authorial presence in the text and to establish contact with their readers (Khalid, 2013; Ntsane, 2015).

Similarly, the second concern of this study was to know 'Do Pakistani English newspaper editorial writers use modals to influence readers' mind and manipulate opinion?' Main aim behind this question was to make the readers aware of the fact that editorialists tend to use the said verbs to establish either a favorable or unfavorable bias throughout the text to manipulate their readers' opinion.

In this regard, it is evident that the said editorialists have made a frequent use of the different types of modals including modal auxiliaries, modal adjectives, evaluative adverbs, knowledge verbs, reporting verbs etc. This means that the editorial writers have reported the events, under their discussion in editorials, with their own attitude. To increase the degree of modality, the writers of editorials have made an excessive use of modal adverbs like surely, truly and unlikely to subjectively define the situations. Similarly, they have also used evaluative adverbs to mark desirability towards the state of affairs. In the same way, the writers of editorials have also made use of reporting verbs like claim, hope and doubt which is the clear indication that the said editorialists have injected their attitude and opinion into truth value of the content reported in the editorials (Ntsane, 2015).

Modality, in reality, is taken as a speaker's attitude or opinion toward a proposition or a state of affairs described in the proposition (Lyon, 1977; Quirk, et al. 1985). Meaning thereby is that the speakers or writers make use of modality to mark their attitude or opinion in the texts or talk. Similarly, a characteristic of modality is that it is judgemental in nature (Palmer, 2007) and involves the manifestation of judgements or evidences about the actual condition of the situations (Chafe \& Nichols, 1986; Palmer, 2007). As modality expresses the opinion of the speakers and writers, it does not have any assurance of truth of the propositions (Papafragou, 2005). Hence, no person can find even a single entirely objective, unbiased and value free text. In fact, it is the writers' authorial interest, view point and vision which defines the essence of the style of a story and gives the story a 
M. Ahmad, et al.

particular "feel" and "colour" (Simpson, 1993: 5). This feel or colour develops a particular stance of the writer in an editorial. In fact, the stance of a newspaper is affected by different factors i.e. homophily notions (Katz \& Lazarfeld, 1955), commercial factors (Tawab, 2000), military influence (Gadzekpo, 2009; Nunoo, 2016), gatekeeping process (Blazhevski, 2018; Nunoo, 2016), economic as well as political factors (Nworgu, Okoro \& Obi, 2017) and this stance is well reflected through editorial lines. Lawal (2015) adds that editors have to follow the ideology of the newspaper and in the view of Henry and Tator (2002) the authors create a larger ideological position of the owners and managers of each newspaper. Therefore, they make use of modals subjectively. Additionally, in the opinion of Hayat and Juliana, the stance of a newspaper is affected by the proprietary structure, newspaper's policy and the political condition in which a newspaper is being published (2016). Newspaper stories go through complex inclusion and exclusion by a gatekeeping process and are mostly influenced by pressure (Nunoo, 2016). Okengwu (1987) cited in Nworgu, Okoro and Obi (2017) adds that the newspaper stories are affected by faulty and impressionistic analyses (1987). The choice of topics, number of pages and articles in a newspaper and their positioning are the matter related to gatekeeping (Blazhevski, 2018). According to Lippmann (1954) cited in Blazhevski (2018):

every newspaper when it reaches the reader is the result of a whole series of selections as to what items shall be printed, in what position they shall be printed, how much space each shall occupy, what emphasis each should have. There are no objective standards here. There are conventions (p.146).

Thus in the view of Porten-Chee (2017), what a newspaper concerns is the notion of "agenda building and agenda framing" (p. 100) with a purpose to "shape the weight and perspectives of different issues" (P. 101). Therefore editorials, being the main voice of a newspaper's editor or proprietor, can also be influenced and biased as well. In fact, the editorials have already been reported to present (1) institutional voice (Hindman, 2003; Kelling \& Thomas, 2018), (2) project organizational stance (Gajevic, 2016), (3) are affected by the notions of homophily (Katz \& Lazarsfeld, 1955) and (4) also are value oriented (Porten-Chee, 2017). In the view of Rosenfeld (2000), editorials provide subjective evaluation of highly debated and contested issues whereas according to Golan and Lukito (2017), editorials give voice to the newspaper's institutional worldview. Editorials, says Indarti (2018), are written with the purpose to influence readers' opinions on controversial issues. In the view of Fowler (2013), newspaper editorials foreground and offer values and beliefs employing textual strategies. These textual strategies are modal verbs (Fowler, 2013; Herndon, 1976).

\section{CONCLUSION}

The discussion of above results leads to the conclusion that prediction, possibility and necessity are the most important features of Pakistani English newspaper editorials. Thus, it can be said that Pakistani English newspaper editorialists are mainly concerned with presenting 'what will happen', 'what can happen' and 'what should happen'. Moreover, the Pakistani editorialists not only report information about news events but they also provide the readers with personal judgements and stances which are realized through different modal verbs, evaluative verbs, knowledge verbs, reporting verbs, necessity modals, possibility modals and prediction modals. It clearly means that Pakistani English newspaper editorials are marked with editors' or institutional stance. To manage the readers' negative perception about the said stance, the editorialists make 
Online Journal of Communication and Media Technologies, 2019

a skillful use of intermediate modals. Therefore, study suggests the readers of Pakistani English newspaper editorials to be conscious of the fact that the said editorials might be biased, affect their mind and manipulate opinions.

\section{REFERENCES}

Adams, H., \& Quintana-Toledo, E. (2013). Adverbial stance marking in the introduction and conclusion sections of legal research articles. In Revista de lingüistica y lenguas aplicadas (Vol. 8, No. 1, pp. 13-22). Editorial Universitat Politècnica de València. https://doi.org/10.4995/rlyla.2013.1028

Biber, D. (2004). Historical patterns for the grammatical sarking of stance: A crossregister comparison. Journal of Historical Pragmatics, 5, 107-135. https://doi.org/10.1075/jhp.5.1.06bib

Biber, D., Johansson, S., Leech, G., Conrad, S., \& Finegan, E. (1999). Longman grammar of spoken and written English. London: Longman.

Bista, K. (2009). On 'yes, we can': Linguistic power and possibility. Journal of English for Specific Purpose, 3(24), 34- 50.

Blazhevski, B. (2018). The selection of news in the international reporting of the Macedonian, Slovenian and Serbian daily newspapers (2013-1989-1983). Online Journal of Communication and Media Technologies, 8(2), 145-164. https://doi.org/10.12973/ojcmt/2359

Bonyadi, A. (2011). Linguistic manifestations of modality in newspaper editorials. International Journal of Linguistics, 3(1), 1-13.

Butler, C. S. (1990). Qualifications in science: Modal meanings in scientific texts. The Writing Scholar: Studies in Academic Discourse, 3.

Chafe, W. L., \& Nichols, J. (1986). Evidentiality: The linguistic coding of epistemology. Ablex Pub Corp.

Chang, P. (2010). Taking an effective authorial stance in academic writing: Inductive learning for second language writers using a stance corpus (doctoral dissertation). The University of Michigan, United States of America. Retrieved February 3, 2019 from https://deepblue.lib.umich.edu/bitstream/handle/2027.42/77860/peichin_1.pdf? ...1

Chang, P. (2012). Using a stance corpus to learn about effective authorial stance-taking: A textlinguistic approach. ReCALL, 24(2), 209-236. https://doi.org/10.1017/S0958344012000079

Chang, P., \& Schleppegrell, M. (2011). Taking an effective authorial stance in academic writing: Making the linguistic resources explicit for L2 writers in the social sciences. Journal of English for Academic Purposes, 10(3), 140-151. https://doi.org/10.1016/j.jeap.2011.05.005

Chang, P., \& Schleppegrell, M. (2016). Explicit learning of authorial stance-taking by L2 doctoral students. Journal of Writing Research, 8(1), 49-80. https://doi.org/10.17239/jowr-2016.08.01.02

Coates, J. (1983). The semantics of the modal auxiliaries. London: Croom Helm.

Fowler, R. (2013). Language in the news: Discourse and ideology in the press. London: Routledge. https://doi.org/10.4324/9781315002057

Gadzekpo, A. (2007). Fifty years of the media's struggle for democracy in Ghana: Legacies and encumbrances. Ghana Studies, 10, 89-106.

Gajevic, S. (2016). Journalism and formation of argument. Journalism, 17(7), 865-881. https://doi.org/10.1177/1464884915621625 
M. Ahmad, et al.

Golan, G. J., \& Lukito, J. (2017). Newspaper editorial pages frame China similarly. Newspaper Research Journal, 38(2), 215-230. https://doi.org/10.1177/0739532917716177

Gotti, M. (2003). Shall and will in contemporary English: A comparison with past uses. Modality in Contemporary English, 12. https://doi.org/10.1515/9783110895339.267

Hall, H. L. (2003). Junior high journalism. Tailor \& Francis, US.

Halliday, M. A. (1976). System and function in language: Selected papers.

Halliday, M. A. K. (1994). An introduction to functional grammar (Second Edition). London: Edward Arnold.

Halliday, M. A. K. (2004). Introduction: How big is a language? On the power of language. The Language of Science, 5.

Halliday, M. A. K., \& Hasan, R. (1989). Language, context, and text: Aspects of language in a social-semiotic perspective. Oxford: Oxford University Press.

Hayat, N., \& Juliana, A. W. (2016). A comparative analysis of Pakistani English newspaper editorials: The case of Taliban's attack on Malala Yousafzai. Pertanika Journal of Social Sciences \& Humanities, 24(3), 1087-1101.

He, Y., \& Wang, H. (2012, July). A corpus-based study of epistemic modality markers in Chinese research articles. In Workshop on Chinese Lexical Semantics (pp. 199-208). Springer, Berlin, Heidelberg.

Henry, F., \& Tator, C. (2002). Discourse of domination: Racial bias in the Canadian English- language press. Toronto: University of Toronto Press. https://doi.org/10.3138/9781442673946

Herndon, J. H. (1976). A survey of modern grammars; London: Holt, Rinehart and Winston.

Hindman, E. B. (2003). The princess and the paparazzi: Blame, responsibility, and the media's role in the death of Diana. Journalism \& Mass Communication Quarterly, 80(3), 666-688. https://doi.org/10.1177/107769900308000311

Holmes, J. (1988). Doubt and certainty in ESL textbooks. Applied Linguistics, 9(1), 21-44. https://doi.org/10.1093/applin/9.1.21

Huddleston, R., \& Pullum, G. (2005). The Cambridge grammar of the English language. Zeitschrift für Anglistik und Amerikanistik, 53(2), 193-194. https://doi.org/10.1515/zaa-2005-0209

Hunston, S., \& Thompson, G. (2000). Evaluation in text: Authorial stance and the construction of discourse. Oxford: Oxford University Press.

Hyland, K. (1994). Hedging in academic writing and EAP textbooks. English for Specific Purposes, 1(3), 239-256. https://doi.org/10.1016/0889-4906(94)90004-3

Hyland, K. (1996). Writing without conviction? Hedging in science research articles. Applied Linguistics 17, 433-454. https://doi.org/10.1093/applin/17.4.433

Hyland, K. (1998). Boosters, hedges and the negotiation of academic knowledge. Text, 18(3), 349-382. https://doi.org/10.1515/text.1.1998.18.3.349

Indarti, D. (2018). Syntactic complexity of online newspaper editorials across countries. Studies in English Language and Education, 5(2), 294-307. https://doi.org/10.24815/siele.v5i2.11320

Katz, E., \& Lazarsfeld, P. F. (1955). Personal influence. The part played by people in the flow of mass communication. New York: Free Press. 
Online Journal of Communication and Media Technologies, 2019

Kelling, K., \& Thomas, R. J. (2018). The roles and functions of opinion journalists. Newspaper Research Journal, 39(4), 398-419. https://doi.org/10.1177/0739532918806899

Khalid, P. Z. B. M. (2013). Modality analysis of the newspaper articles about the Scottish Ship RMS Queen Elizabeth. Academic Journal of Interdisciplinary Studies, 2(9), 458461. https://doi.org/10.5901/ajis.2013.v2n9p458

Kuppers, A. (2012). Authorial presence and stance in German and French letters to shareholders. Subjectivity in Language and Discourse, 355.

Lawal, O. A. (2015). Pragmatics of truth and modality in newspaper editorials: An example of the punch and the tribune. Theory and Practice in Language Studies, 5(4), 688-693. https://doi.org/10.17507/tpls.0504.03

Lyons, J. (1977). Semantics. Cambridge: Cambridge University Press.

Maks, E. \& Vossen, P. (2010). Annotation scheme and gold standard for Dutch subjective adjectives. Working paper, ELREC 2010.

Mirahayuni, N. K. (2002). Investigating textual structure in native and non-native English research articles: Strategy differences between English and Indonesian writers. University of New South Wales.

Nartey, M., \& Yankson, F. E. (2014). A semantic investigation into the use of modal auxiliary verbs in the manifesto of a Ghanaian political party. Int J Humanities Soc Sci, 4(3), 21-304.

Ngula, R. S. (2017). Epistemic modal verbs in research articles written by Ghanaian and international scholars: a corpus-based study of three disciplines. Brno studies in English, 43(2), 5-27. https://doi.org/10.5817/BSE2017-2-1

Ntsane, M. F. S. (2015). The management of writer-reader interaction in newspaper editorials. Ghana Journal of Linguistics, 4(2), $108-123$. https://doi.org/10.4314/gjl.v4i2.5

Nunoo, I. (2016). Determinants of news selection in the Ghanaian print media: A study of the daily graphic. Online Journal of Communication and Media Technologies, 6(3), 99-120.

Nworgu, K. O., Okoro, N., \& Obi, C. (2018). The press and Nigeria's foreign policy: A content analysis of selected issues (1985-1995). Online Journal of Communication and Media Technologies, 8(3), 245-257. https://doi.org/10.12973/ojcmt/2659

Palmer, F. R. (2007). Mood and modality. Beijing: World Book Publishing Company.

Panocová, R. (2008). Expressions of modality in biomedical texts. SKASE Journal of Translation and Interpretation 3(1), 82-90.

Papafragou, A. (2005). Epistemic modality and truth conditions. Delaware: University of Delaware Press.

Pho, P. (2013). Authorial stance in research articles: Examples from applied linguistics and educational technology. Springer. https://doi.org/10.1057/9781137032782

Porten-Chee, P. (2017). Frame building the "social digitization" in the German press. Online Journal of Communication and Media Technologies, 7(4), 96-116.

Qian, L. (n. d.). Use of modal verbs in English writing by EFL learners. Retrieved November 23, 2018 from https://www.birmingham.ac.uk/Documents/collegeartslaw/corpus/.../paper394.pdf

Quirk, R., Greenbaum, S., Leech, G., \& Svartvik, J. (1985). A Comprehensive grammar of the English language. London: Longman. 
M. Ahmad, et al.

Rosenfeld, S. S. (2000). The op-ed page: A step to a better democracy. Harvard International Journal of https://doi.org/10.1177/1081180X00005003002

Sadia, S., \& Ghani, M. (2018). Modality in editorials of Pakistani English newspapers: A corpus based study. International Journal of English Linguistics, 9(1), 144-151. https://doi.org/10.5539/ijel.v9n1p144

Shayegh, K. (2012). Modality in political discourses of Barack Obama and Martin Luther King. Trends in Advanced Science and Engineering, 3(1), 2-8.

Shayegh, K., \& Nabifar, N. (2012). Power in political discourses of Barack Obama. Journal of Applied Scientific Research, 2(4), 3481-3491.

Siddique, A. R. (2017). Metadiscourse analysis of Pakistani English newspaper editorials: A corpus based study (unpublished master thesis). Department of Applied Linguistics, Government College University Faisalabad, Pakistan.

Simpson, P. (1993). Language, ideology and point of view. London: Routledge. https://doi.org/10.4324/9780203312612

Smith, N. (2003). Changes in the modals and semi-modals of strong obligation and epistemic necessity in recent British English. In R. Facchiretti, M. Krug \& F. Palmer (eds.), Modality in contemporary English (pp.241-266). Berlin and New York: Mouton de Gruyter. https://doi.org/10.1515/9783110895339.241

Taavitsainen, I. (2001). Evidentiality and scientific thought-styles: English medical writing in late middle English and early modern English. In Modality in specialized texts: Selected papers of the 1st CERLIS Conference (pp. 21-52). Bern: Peter Lang.

Tawab. (2000). Editorial coverage of women right. Unpublished Master's Thesis, Punjab University, Lahore.

Wang, J., \& Jiang, F. (2018). Epistemic stance and authorial presence in scientific research writing. In Intercultural perspectives on research writing (pp. 195-216). John Benjamin Publishing Company. https://doi.org/10.1075/aals.18.09wan

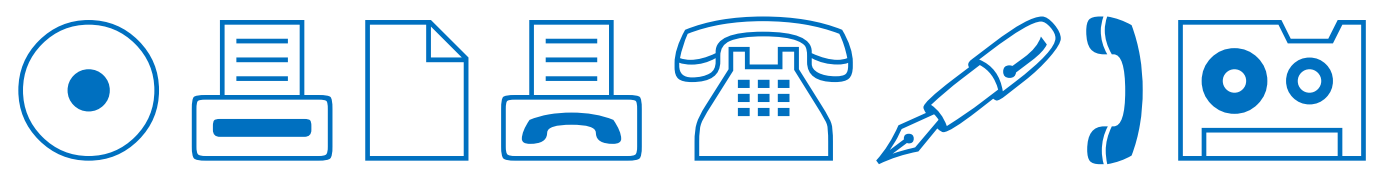

